\title{
Basement Configuration and its Impact on Permian-Triassic Prospectivity in Kuwait
}

\author{
Parmjit Singh (Kuwait Oil Company < pasingh@kockw.com>), Riyasat Husain (Kuwait Oil \\ Company), Ahmad Al-Kandary (Kuwait Oil Company) and Abdulaziz Al-Fares (Kuwait Oil \\ Company)
}

\begin{abstract}
Summary
Petroleum exploration efforts to date primarily have been focused on the Cretaceous and Jurassic targets and very little effort has been made for exploring deeper prospects in Kuwait. The seismic data quality due to its infestation with multiples does not allow for mapping the deeper prospects with confidence. For meeting this objective, an integrated modelling of seismic, gravity, magnetic and borehole data is carried out for generating a basement configuration map to evaluate the likely preservation of the Lower Silurian Qusaiba hot shale. The Qusaiba hot shale is the source for some of the most important petroleum systems of the Middle East and is believed to have charged the Devonian Jauf, Carboniferous-Permian Unayzah and Permian-Triassic Khuff formations.
\end{abstract}

\section{Introduction}

Broad structural architecture of the Kuwait is defined by the NNW-trending Kuwait Arch flanked by the Dibdibba Trough to its west and offshore Kuwait to its east. Considerable flow of high-pressure, high-temperature (HPHT) gas in the Kra-Al Maru Member of the Lower Jilh (Middle Triassic) in deep wells at Mutriba and Kra-Al Maru structures has enhanced the hydrocarbon prospectivity of the Dibdibba Trough for the deeper prospects. In view of the possible potential at deeper levels of Triassic-Paleozoic system, the salt-triggered structures of Kra-Al Maru and Mutriba in the Dibdibba Graben (Singh et al., 2009, 2010) assume greater importance for future deeper exploration. So far only a few wells located on the Kuwait Arch have penetrated the Pre-Khuff sequences.

The Silurian sedimentary package comprising the most prolific source rock, the Qusaiba hot shale, is missing in these wells. No well penetrated the entire Khuff section in the Dibdibba Trough. The deeper anomalous structures and basement faults are mainly obscured on the seismic data due to the presence of multiple events and limited impedance contrast between the Devonian-Silurian and Cambrian-Ordovician sediments (economical basement). To enhance the geological understanding of the trough, integrated modeling has been carried out with the objective to envisage the possible preservation of the Lower Silurian Qusaiba Member in the deepest part of the basin. This unit is the main source of low-sulfur light oil and gas, and one of the most prolific petroleum-generating systems of Khuff and Pre-Khuff in the Middle East region (McGillivray and Husseini, 1992).

\section{Methodology}

In order to meet the objective of estimating basement depth, integrated modelling along sixteen regional seismic lines has been carried out using seismic, gravity, magnetic and well data. The estimated depth to the Khuff using available well and regional velocity model is fairly acceptable. The density values of each formation are picked from density logs and averaged for the similar lithological suites with a weighted average method. The depthconverted seismic sections are used as a bit map for 23/4D modeling to guide the geometry of the density polygons. The density polygon at the economic basement level and top of Hormuz Salt are exported to OpenWorks along the seismic lines. Horizon correlation at these levels is 
carried out with additional 25 depth-converted dip and strike seismic sections (grid $5 \times 5 \mathrm{~km}$ ) for better control for generating regional basement configuration map (Figure 1). The major faults are also mapped from integrated models (black dotted lines). The faults in light blue colour dotted lines are mapped from the bandpass filtered magnetic map.

\section{Analysis}

A maximum sedimentary thickness of nearly 28,000 feet in the Dibdibba Trough is estimated (Figure 1). The basement depth near Mutriba and Kra-Al Maru in the Dibdibba Trough is the maximum. The Qusaiba hot shale is inferred to be preserved in the Dibdibba Trough in western Kuwait and enhances the deeper prospectivity. Underlying Phanerozoic strata in Kuwait, there is a faulted Precambrian basement, with alternating horsts and grabens directed along the dominant N-S Arabian trend. The faults mapped from filtered magnetic data and represented by light blue dotted lines are deep-seated and affect Precambrian crystalline basement and might have been reactivated during various tectonic movements of the Arabian Plate. These faults may act as a conduit for the migration of hydrocarbons sourced by the Qusaiba hot shale for the Permian-Triassic structural traps. The basement configuration map has important implications for Permian-Triassic prospectivity of Kuwait.

\section{Conclusions}

The integrated modeling using seismic, gravity, magnetic and well data helped in understanding the basement configuration, Khuff and Pre Khuff sedimentary fill and basement faults. These elements are envisaged to have influenced the Permian-Triassic petroleum system.

\section{Acknowledgments}

The authors express their thanks to the Ministry of Oil, the State of Kuwait and the Management of Kuwait Oil Company for permission to publish this paper.

\section{References}

McGillivray, J.G. and M.I. Husseini 1992. The Paleozoic petroleum geology of central Arabia. American Association of Petroleum Geologists Bulletin, v. 76, no. 10, p. 14731490.

Singh, P., H. Al-Qallaf, R. Husain and A.A. Sajer 2009. Aborted halokinesis and development of Mutriba structure, Kuwait, Proc. SEG, 79, p. 947-951.

Singh, P., R. Husain, A.A. Sajer, A. Al-Fares 2010. Estimating Pre-Khuff thickness and delineating basement configuration in Dibdibba Trough, Kuwait - An integrated model based study. Proc. 80th SEG, p. 1217-1221. 


\section{EAGE}

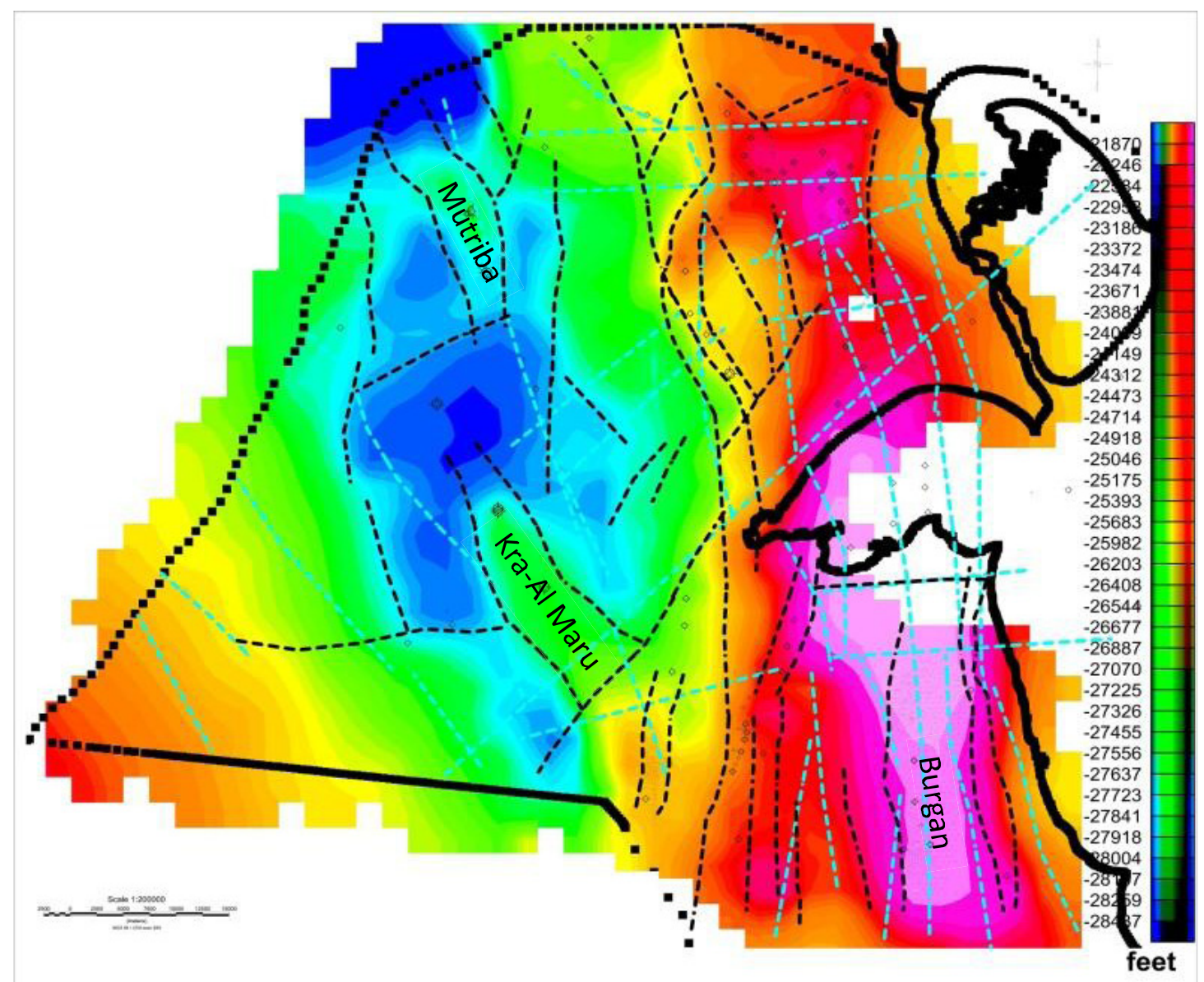

Figure 1: Basement configuration map of onland Kuwait generated from integrated modelling of seismic, gravity, magnetic and borehole data. Black dotted lines are faults mapped from combined modelling of seismic, gravity and magnetic data. Parrot dotted lines are the faults mapped from uplifted basement blocks from bandpass filtered magnetic data. 